\title{
Analysis and Implementation of an Optimal PV Solar Generator in Tropical Zone
}

\author{
Andre YOUMSSI ${ }^{1,2,3, *}$, Emmanuel Patrick FEUDJIO ${ }^{3}$ \\ ${ }^{1}$ Electric Energy Laboratory (LEE), Montreal, Canada \\ ${ }^{2}$ Ecole Polytechnique de Montreal, Succursale Centre Ville, Montreal, Quebec, Canada \\ ${ }^{3}$ Electromagnetic Laboratory \& Process Engineering Laboratory, The University of Ngaoundere, Ngaoundere, Cameroon \\ *Corresponding author: andre.youmssi@yahoo.com
}

Received April 26, 2014; Revised May 25, 2014; Accepted May 28, 2014

\begin{abstract}
Many small size enterprises, other organisms and rural people mostly in underdeveloped countries do not have an easy access to the grid, and are then in the need of a decentralised electric sources which appear as crucial in some cases specially when feeding rural hospitals, or serve for pumping drinkable or irrigation water. Electric Solar Generators Technologies could then efficiently come to rescue. This article focuses on the analysis of keys factors for a design, and an implementation of such a PV Solar Generator. We have in that aim proceeded to a study of the state of art in that domain of Solar Electric Generators, which offered keys parameters of each component of a safe easy maintainable feeding solar system, and lead us to the design notably owing to the software PVSyst, to the implementation of and the experiments of a domestic flat PV solar generator. Results are constituted by the designed schematics, tables and curves of simulated and experiments electric quantities like the maximum delivered powers, and the efficiencies. The article reported an example of a complete PV system installed, and instrumented for data logging. That system included a battery and an inverter to power real loads. The system design parameters comprised the size of the PV array, the battery size, and the power rating of the inverter, as well as the power delivered to the loads. The data logged have been used to evaluate the designed system and to make assessments on how the system design could be improved so that systems of this type could serve the local needs most economically.
\end{abstract}

Keywords: modelling, experiments, $P V$ generator (PEF), Power Electronics

Cite This Article: Andre YOUMSSI, and Emmanuel Patrick FEUDJIO, "Analysis and Implementation of an Optimal PV Solar Generator in Tropical Zone.” American Journal of Electrical and Electronic Engineering, vol. 2, no. 3 (2014): 103-116. doi: 10.12691/ajeee-2-3-8.

\section{Introduction}

The whole planet could run out an energy crisis according to International Energy Agency which has indicated that the needs will triple by the years 2050 . Some studies of Professors Kenneth Deffeyes, from Princeton University (2006) and Fredrik Robelius, from Uppsala University in Sweden (2007), show that the oil production has reached a peak value of 84.5 millions of gallons per day, and that the oil may not in finely compensates the needs rate, and this mainly because of the production goes diminishing. So many researches are carried out all over the world on the searching of new energy sources that could satisfy those needs. It could also be noticed that many people live in some geographical zones were the grid is technically impossible or really difficult to be implemented. Renewable energy sources then come to be considered with great interests among the researched new sources because they respect the environments and their present use does not fortunately affect their future use. Solar Energy seems to constitute an interesting such renewable sources that may come to rescue for challenging in one hand grid feeding in difficult geographical zones, and on the other hand guaranties the future in case of energy crisis. This solution then appears crucial, specially for people in rural zones where the grid is absent, and deeply recommended by many world development organisms like the ASEAN Centre for Energy, Environment and Development Network for Africa, and the "Organizacion Latino americana de Energia".

A PV generator may then in some cases be preferable for many reasons: It brings autonomy for the systems that are not connected to the grid and, it could come to rescue in the case of a black out to those that are connected to the grid. The PV solutions also seem to be of interest for countries with grids fed by dams because the water could then be used with more efficiency [1-10]. A PV panel's generator equipped with batteries seems the most advantageous among the decentralised electricity production systems like generating units. The context of our study is tropical zones which could received per year an irradiance of $2.065 \mathrm{kWh} / \mathrm{m}^{2}$, which means that a square meter of PV panels if used in that area could help covering during 20 months the energy needs of a family who spends a $100 \mathrm{kWh}$ per month. 
We will try in this study to perform a state of the art in that domain of PV solar generation and then try to reach after a deep analysis the key factors that will help designing and implementing an optimal PV panel's generator. We then consider Saheb-Koussa \& Haddadi (2007) well known one diode model of a PV panel in order to express the power delivery with respect to the voltage. Our study then brings out the different technologies of components that could constitute the PV panel's generator, and the conditions of their use. Our article also addresses the energy conservation problematic and the maintenance of the installed PV generator.

We will so spend some efforts to answer the following hypothesis:

- Why it important to focus on the maximum power delivered, Pmax?

- How could we make a productive choice among all the PV systems?

- How could Pmax be influenced by the geographical position of the PV panel, by the sun irradiance, and by the temperature?

- How do the batteries behave with respect to the called current rate?
- What are the limits of the PV system?

- And the question of safety?

This article will try to answer those interrogations through three main parts: one on the literature on the domain, the second on the equipments and the methodologies of the studies, and the last one on the results and the discussions.

\section{Review on the Modeling of PV Generators - Objectives of the Study}

We present here well known PV cell modeling and similarly well known and well documented how variations of the position of a PV panel affect the output power and energy capture. Our main goal here is to remind how the Maximum Power Point (MPP) could be predetermined from Power-Voltage, and Current-Voltage curves that can also be predetermined for a given PV panel. We then explained how the voltage drops that lead to MPP points when loaded the PV system can be predetermined owing to the characterization and the identification of the parameters of the chosen model.

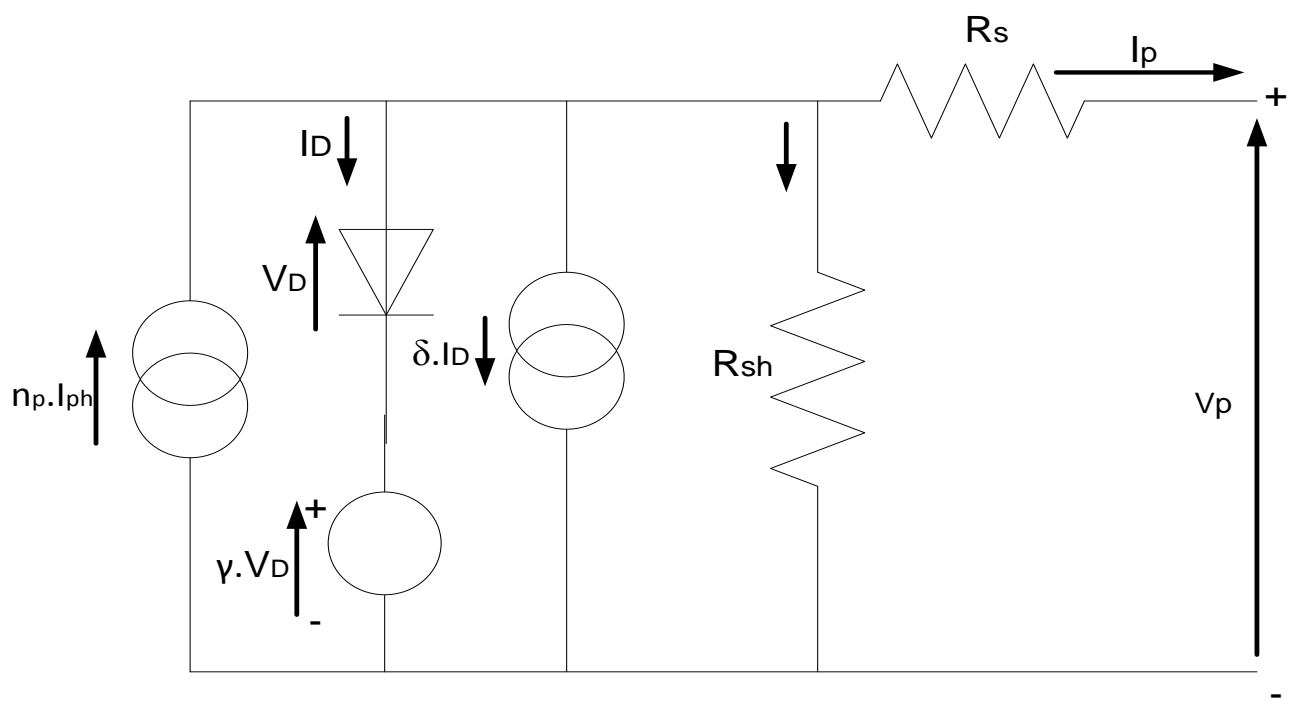

Figure 1. Complete Model of a PV Panel [1-21]

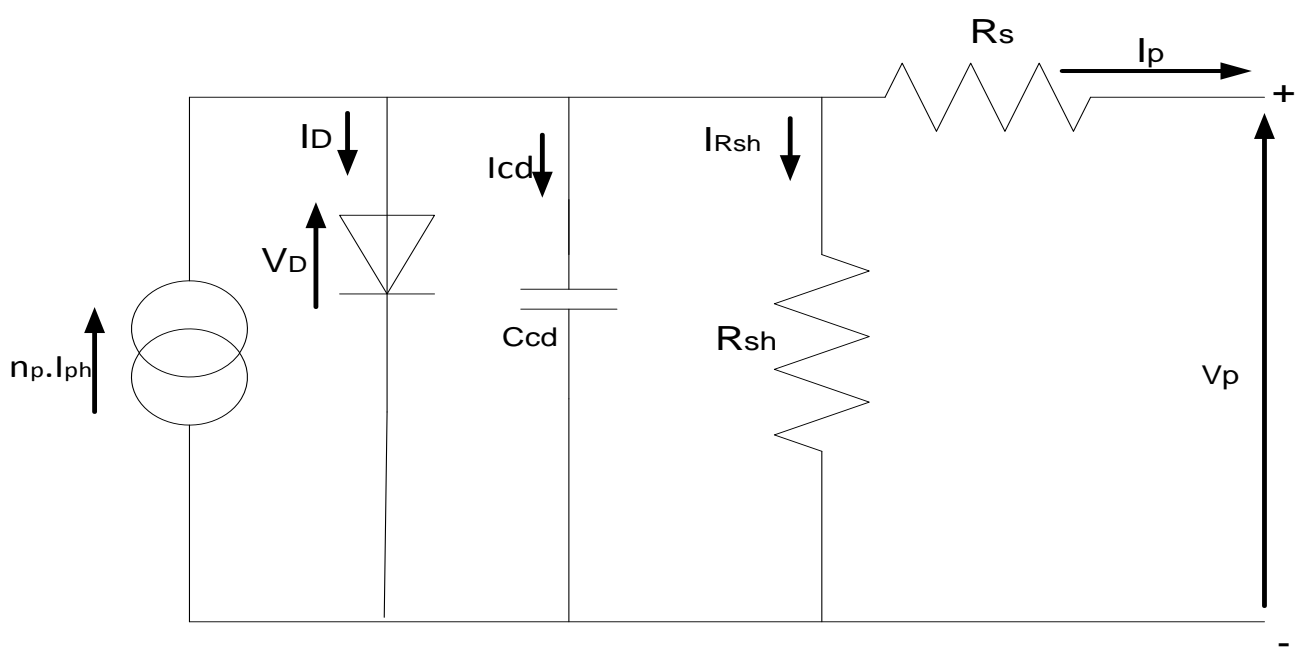

Figure 2. Model of a PV Panel with Rsh, Rs and a Capacitor [1-21] 


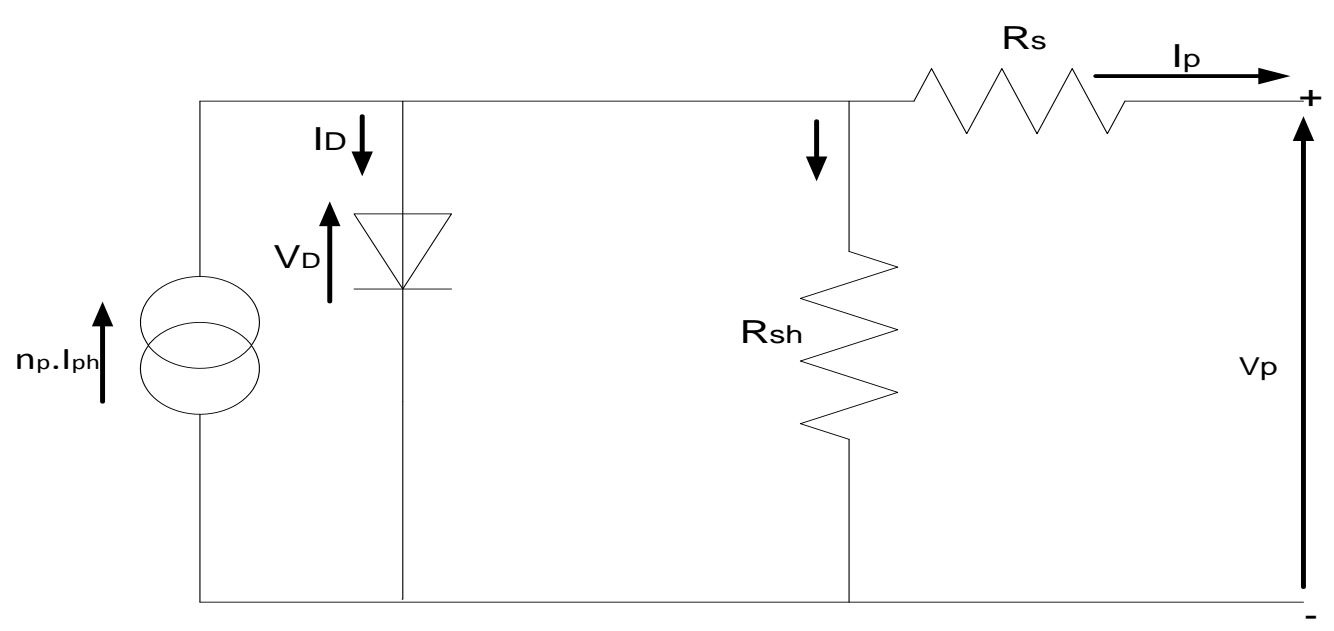

Figure 3. Model of a PV Panel with Rsh and Rs [1-21]

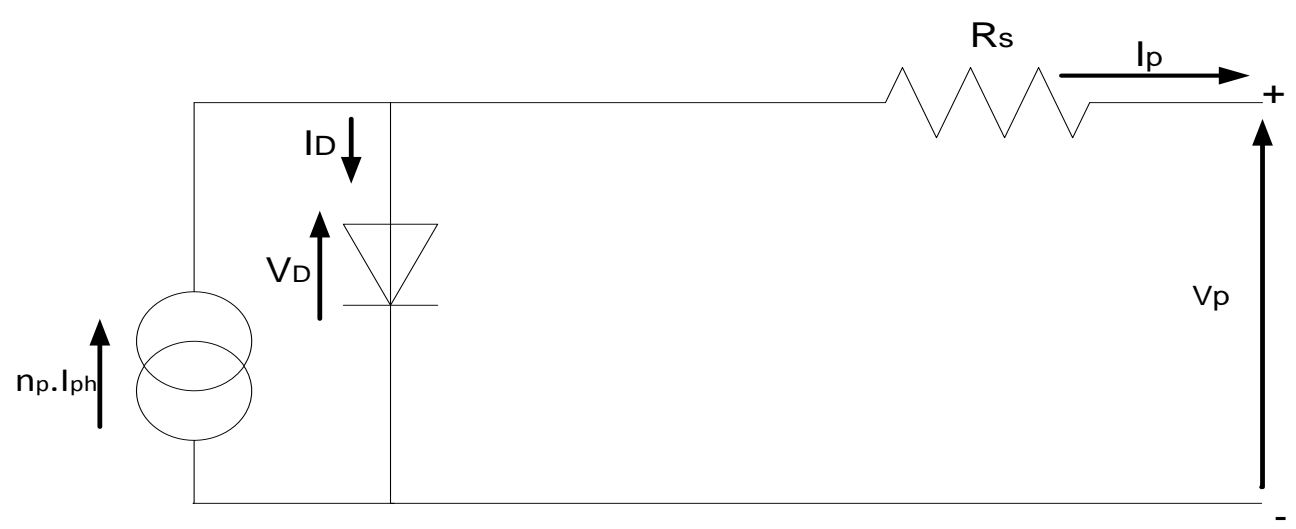

Figure 4. Simplified Model of a PV Panel [1-21]

It is now well known that PV cells behave as photo p-n junction that operates with very low efficiency. They so needed to be judiciously connected in order to obtain maximum power at the outputs [1,2]. The PV generators need to be controlled and commanded to operate at that point (Maximum Power Point, named MPP). They should then be modelled and characterised. The scientific literature on PV generators shows many types of models $[1,2,3,4,5]$. It so comes out that the Figure 1 to Figure4 seems to be the most used in the modeling of PV Generators (Figure 1 - Figure 6), each presenting its particular advantages.

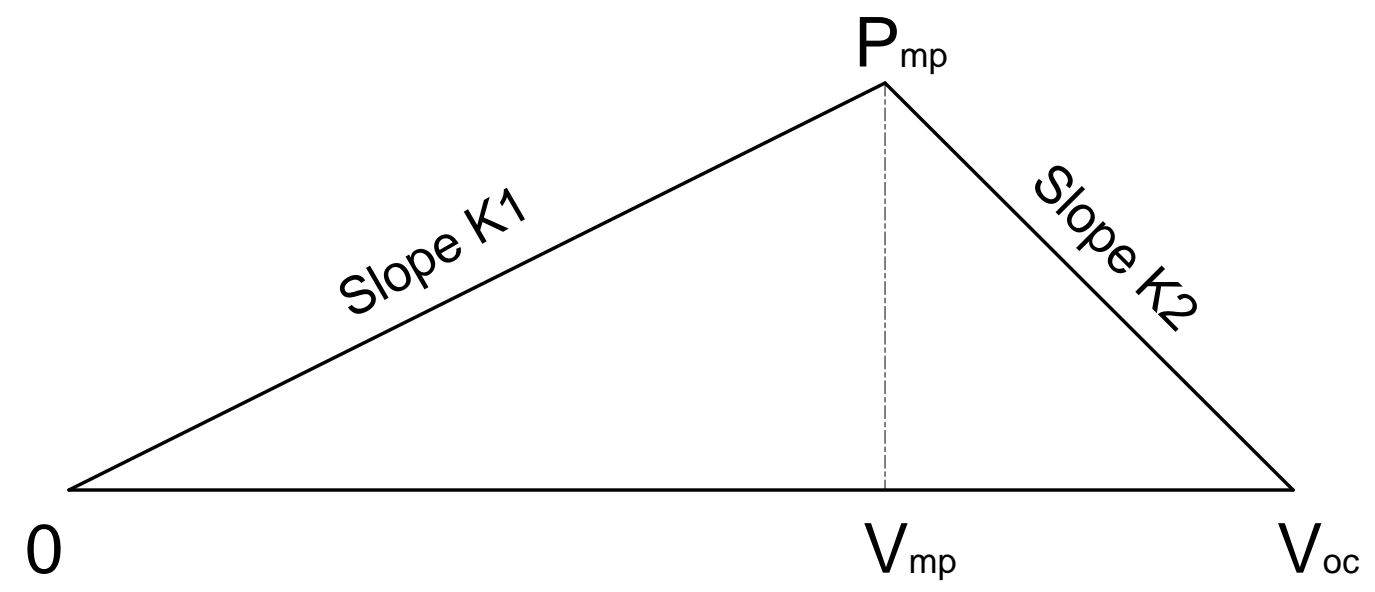

Figure 5. Deduced general modeling of the Power-Voltage Curve

All the models insist on one hand on the series output resistance Rs and on the other hand on the source current np.Iph, that comes from the direct conversion of the sun irradiance into an electric current. All those models also remind that the PV cell is a p-n junction which is here represented by a classic diode. So it can be deduced from those models that the PV-Generator will behave like a classic DC voltage source with an internal resistor which is here Rs, and which will responsible for the voltage drop when the output current will increase, the maximum current being reached at short-circuit that corresponds to zero voltage and zero power. The maximum voltage Voc will so obtained with a zero current that also corresponds to zero power. Classic values of Voc are between $0.4 \mathrm{~V}$ to 
$0.6 \mathrm{~V}$ for silicium cells with $12 \mathrm{~mA} / \mathrm{cm}^{2}$ for the shortcircuit currents and under standards conditions (STC). It is so easy to demonstrate that a maximum power Pmp will be reached at a couple (Vmp, Imp) that corresponds to the MPP operating point. It can so be deduced from all the models used till now (Figure 1 - Figure4), that the powervoltage characteristics of the PV-generator can then be modelled by the general graph on Figure 5 . The characterisation of the PV generator could so lead to the values of the parameters that constitute the chosen models (Figure 1 - Figure 4), and then to the control of the voltage drop $\Delta \mathrm{V}=\mathrm{Voc}-\mathrm{Vmp}$ on Figure 5 .

The scientific literature also indicates that the generated electric current np*Iph could drastically increase with an optimal geographic position of the PV panel [2-8]. That optimal position needs to be known and set using the mechanical system that holds the panels. The angles $\alpha, \beta$, and $\gamma$ should then be implemented (Figure 6.a).

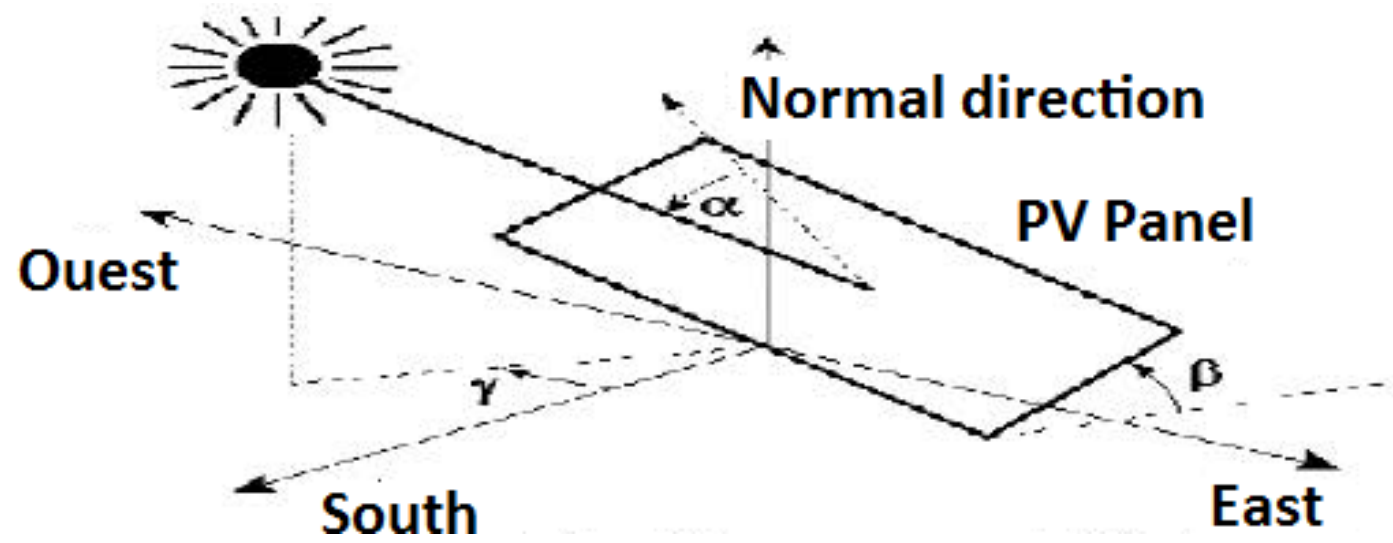

Figure 6. a: Possible Variations of the position of a PV Panel

Our study focuses on tropic regions that corresponds to the maximum W. $\mathrm{m}^{-2}$ in the world and where it is known that the solar irradiance over a year which is almost
$1.6 * 10^{21}$ Wh may lead to satisfy if transformed the present world annual need of energy (almost $17.3 * 10^{15}$ ) Wh (Figure 6.b) and as it is well explained by Jean Zin author.
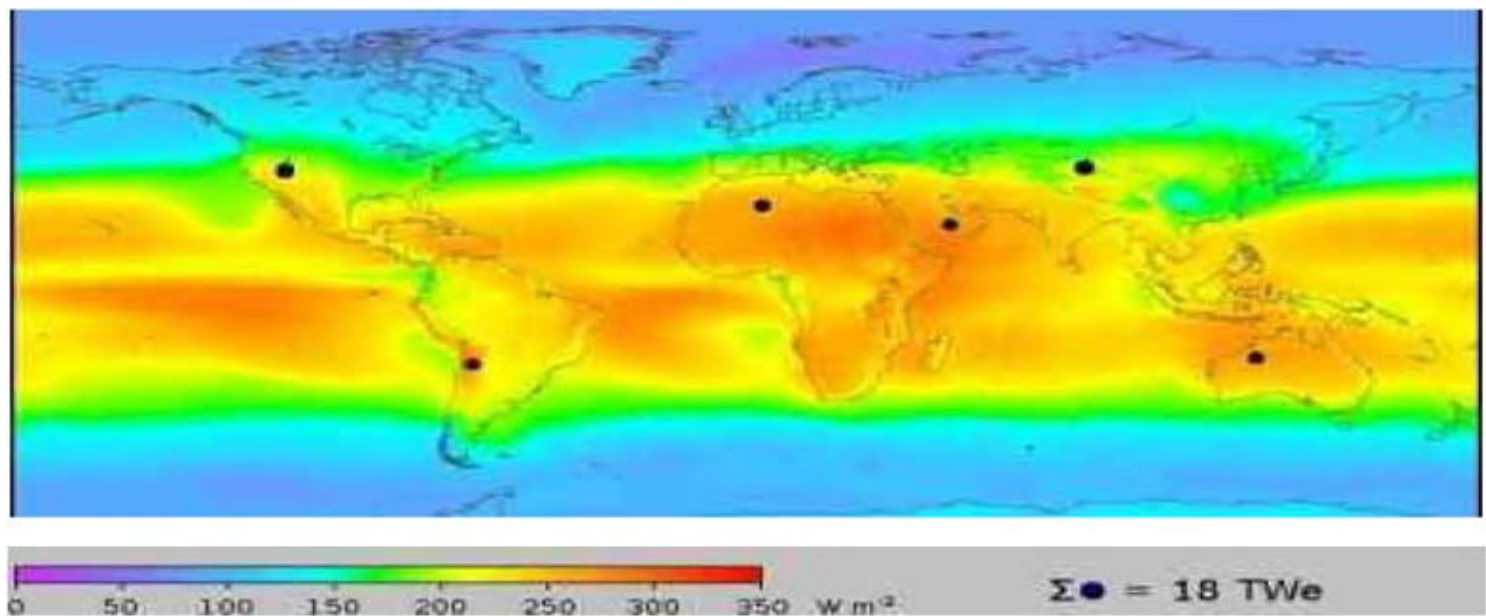

Figure 6. b: World Solar Irradiance - Solar potential of Tropical zone [6]

We would like to remind that a PV Solar Generator can be or not connected to the grid, it could run with or without a power additional income, and/or an energy storage system. The solar covering rate, also called the LOLP (Loss of Load Probability), as shown on Figure 6.b, constitutes an important data when dimensioning a PV Solar Generator. The value of the LOLP makes the PV Solar Generator critical or not. The PV System designed as an example for data logging was critical, and complete with batteries, inverters and controls. The designating has been in four steps:

1. The power needs per day calculated at a value of $20640 \mathrm{Wh} /$ day.

2. The calculation of the solar covering rate (Figure $6 \mathrm{~b}$ ), which assures the providing of the power a year Along, the estimated minimum irradiance has been evaluated at a value of $4.66 \mathrm{kWh} / \mathrm{m}^{2}$
3. The $12 \mathrm{~V}$ batteries with a capacity calculated at a value of $5733 \mathrm{Ah}$

4. and finally the required PV field to cover the real needs but also all the losses estimated at a value of 5537 Wc which corresponds to 93 modules of 60 wc each.

So a quick hand pre design leads to a $12 \mathrm{~V} / 5733 \mathrm{Ah} /$ $5.54 \mathrm{kWc} / 61 \mathrm{~m}^{2}$, PV Generator. We have used the software PV-Syst in order to obtain optimised parameters of that PV Generator. Such software takes into account:

- The minimum autonomy of the PV system which diminishes the batteries capacity

- The possibility of using alternatives sources when the sun is not at rendezvous

- The solar covering rate and the advantage of running the system at MPP points, which may lead to minimum number of PV panels the author Gilbert CHAMP, indicated. We then came out with an 
optimal PV generator that of the following characteristics for year consumption: 12V/ $2250 \mathrm{Ah} /$ $4.320 \mathrm{kWc} / 42.3 \mathrm{~m}^{2}$

\section{Equipments and Methodologies}

We carried experiments with an example of equipments constituted by: $04 \mathrm{PV}$ modules of 60 Wc with thr dimensions: $\mathrm{Lg}=1.13 \mathrm{~m}$; $\lg =0.52 \mathrm{~m}$; useful area : 0.48 $\mathrm{m}^{2}$, each panel built with 39 Cells. We also used a $80 \mathrm{Wc}$ 36 cells module of dimensions $\mathrm{Lg}=1.20 \mathrm{~m}$; $\mathrm{lg}=0.53 \mathrm{~m}$; and a useful area of: $0.49 \mathrm{~m}^{2}$ (Figure 7). Three junction boxes for $12 \mathrm{~V}, 24 \mathrm{~V}$ and $48 \mathrm{~V}$ modules; Four solar batteries (Figure 8.a); three $12 \mathrm{~V}, 24 \mathrm{~V}, 48 \mathrm{~V} / 20 \mathrm{~A}$ charges regulators (Figures 8.b); $12 \mathrm{~V}-300 \mathrm{~W}-230 \mathrm{~V}-50 \mathrm{~Hz}$ inverters; and many other measurements apparatus (voltmeters...etc.) have been used to instrumented to design and installed the PV system for data logging.

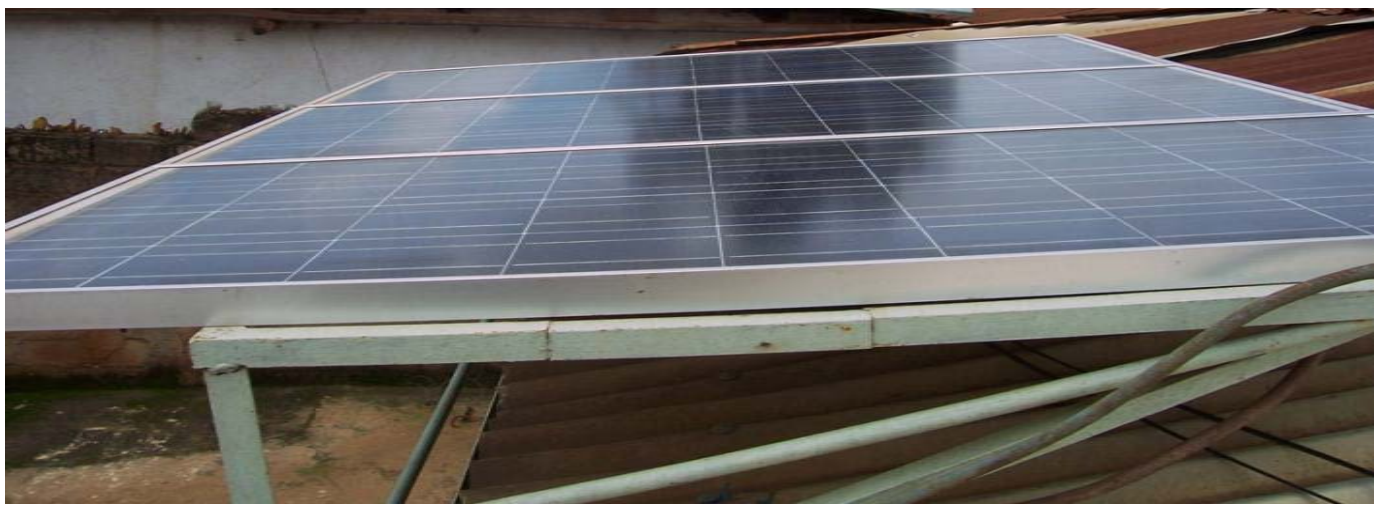

Figure 7. the experimented PV panels

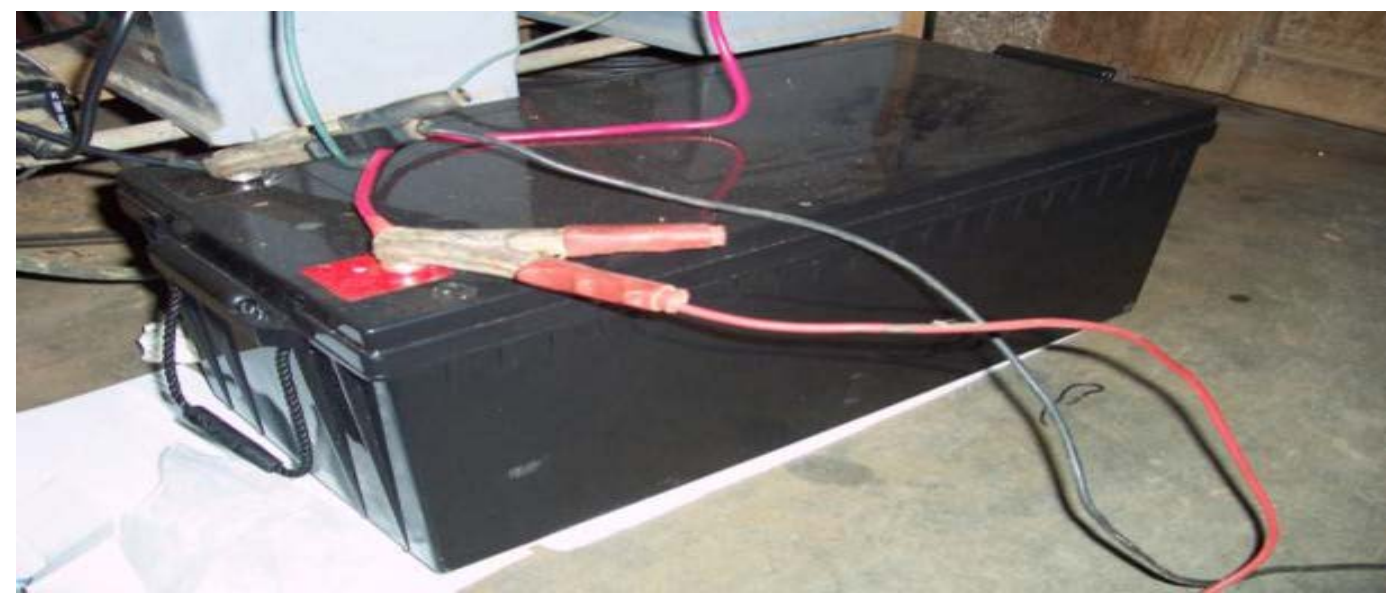

Figure 8. a: Experimented batteries

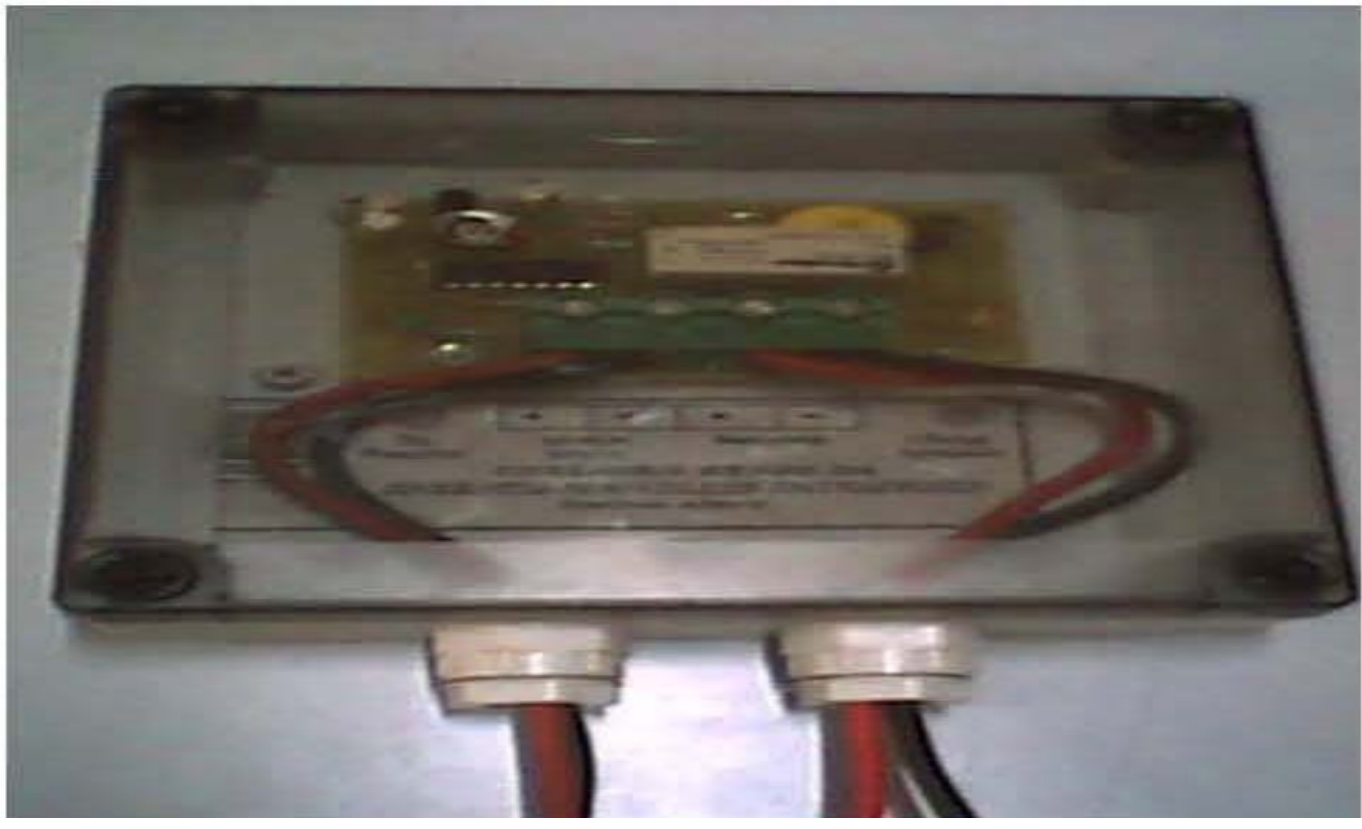

Figure 8. b: The used regulators for Batteries 


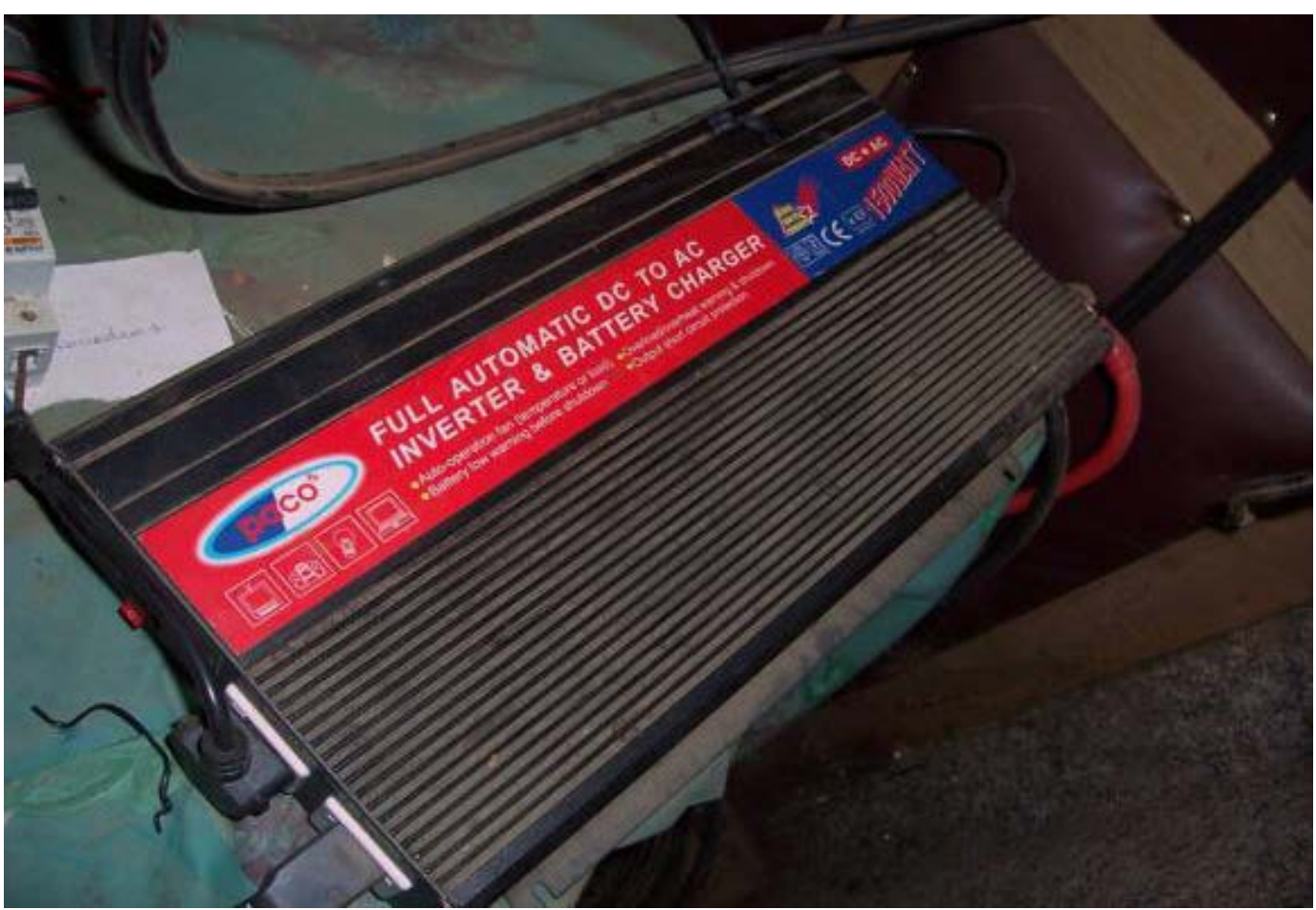

Figure 8. c: Photo of the proposed Inverter

The software PVSyst has also been used to design the PV panels and other components, and also to simulate the running of the system with the possibilities of trying to know what results could be obtained when supposing the variations of different parameters. The influence of the position of the PV Panels and of the time period (the month) have so been predicted and confirmed with experiments with very good accuracy...etc. That software has then served for the simulation of each studied case. We have so come to be capable to compare the simulation and the experiments results, bringing the real system to operate at predicted desired MPP points. We have then used PVSyst software to pre design and simulate our PV system. We have then first performed a rapid pre dimensionnement of the system based on

- The wheather forcast,

- The orientation of the PV pannels

- The real electric charge including all the losses,
- The depth of the batteries discharge

- And the covering rate

We then came out with the power of the PV panel and the capacity of the batteries to be installed.

In the other hand, we have been able to make a simulation through PVsyst going from the first results and then compare with experiments. It should be indicated here that the losses have also been taken into account by the simulations.

\section{Results and Discussions}

We have been obliged to design and build a judicious multi positions stand which has helped to obtain the Maximum irradiance and bring the system to always operate at MPP point which varies with months (Figure 9.a).

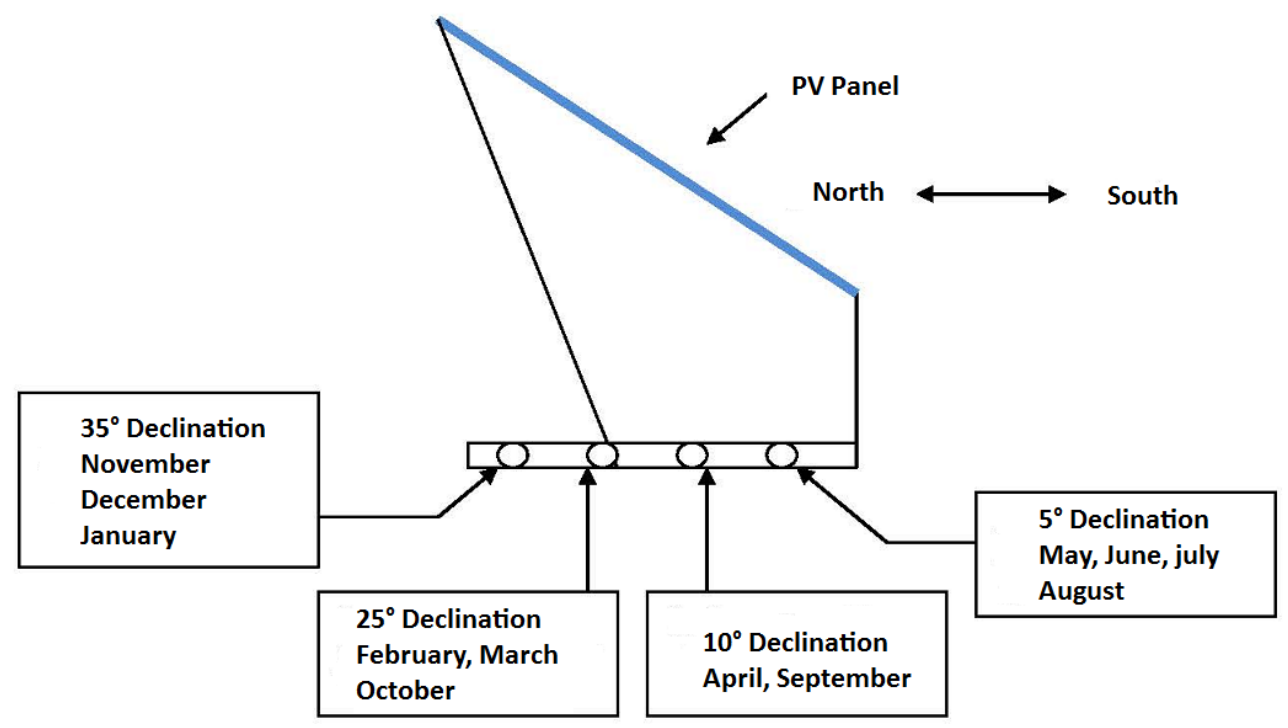

Figure 9. a: Built PV Panel Multi positions stand 
We have then come out with the remarks that the characteristics (optimal positions ...etc) of the installed PV modules were the same like the ones obtained by software simulations (Figure 9.a). The whole designed and installed system can then be represented by the following schematic. On Figure 9.b. The system could then feed Ac and DC charge. The autonomy being assure through batteries (Figure 9.b).

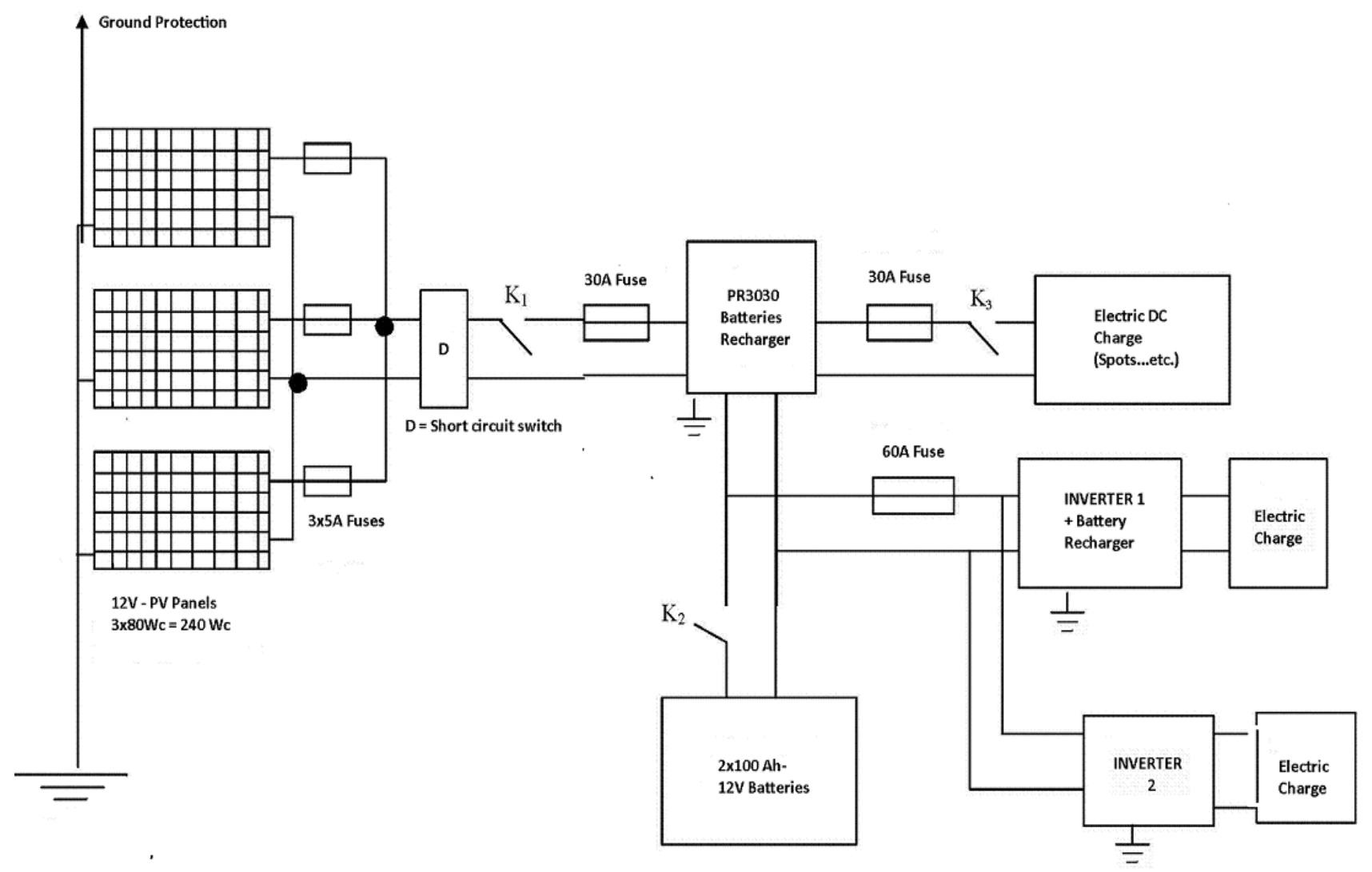

Figure 9. b: Schematic of the designed and installed PV Solar Generator

Some algorithms have been written in the solar systems software PVSyst which have helped simulating the efficiency of a module with the possibility to vary operating cell temperature in on hand, and the irradiance in the other hand, the values of the efficiencies remaining low, under $12 \%$. This is due to the limits encountred in all PV technologies. The silicium poly crystalline $60 \mathrm{Wc}$ that we have used in experimentation generates a maximum of $125 \mathrm{~W} / \mathrm{m}$, while the mono crystalline technology $80 \mathrm{Wc}$, the other module generates $163.1 \mathrm{~W} / \mathrm{m}$ (Figure 10 \& Figure 11).

\section{Efficiency (\%)}

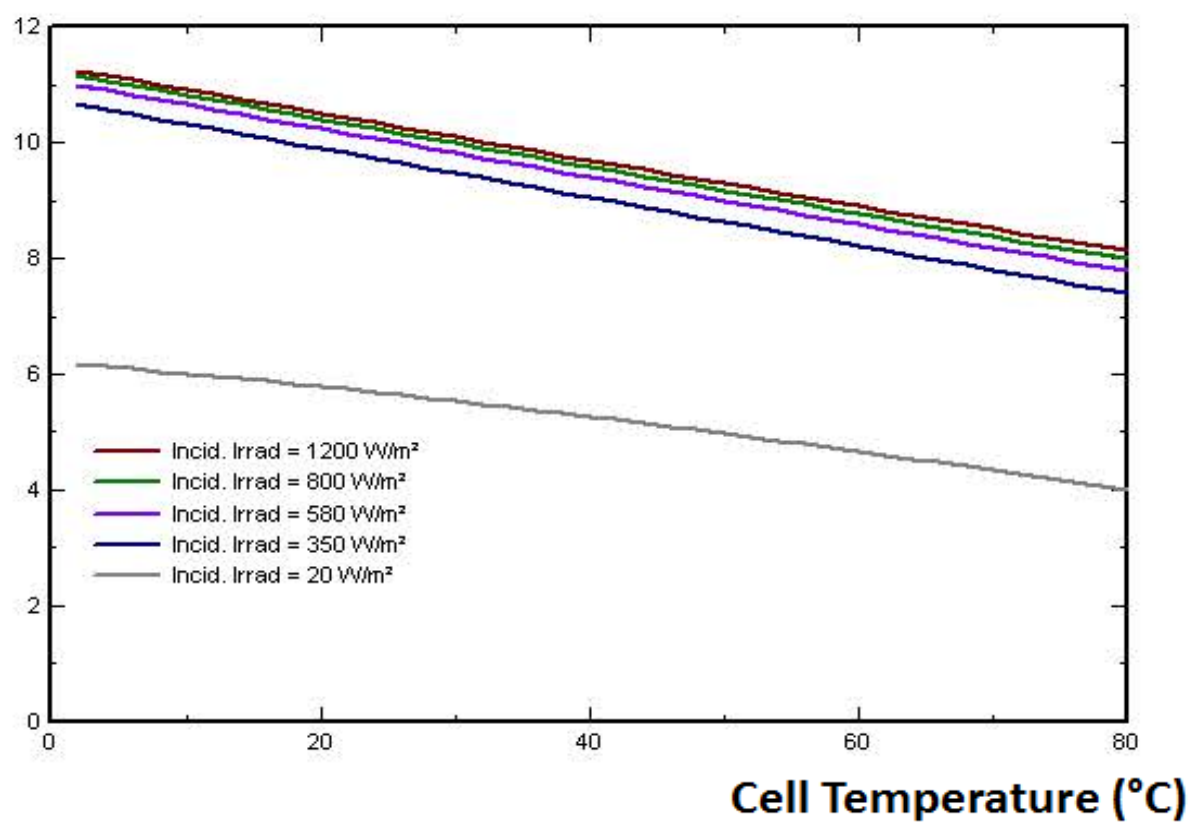

Figure 10. Efficiency with respect to the cell temperature 


\section{Efficiency (\%)}

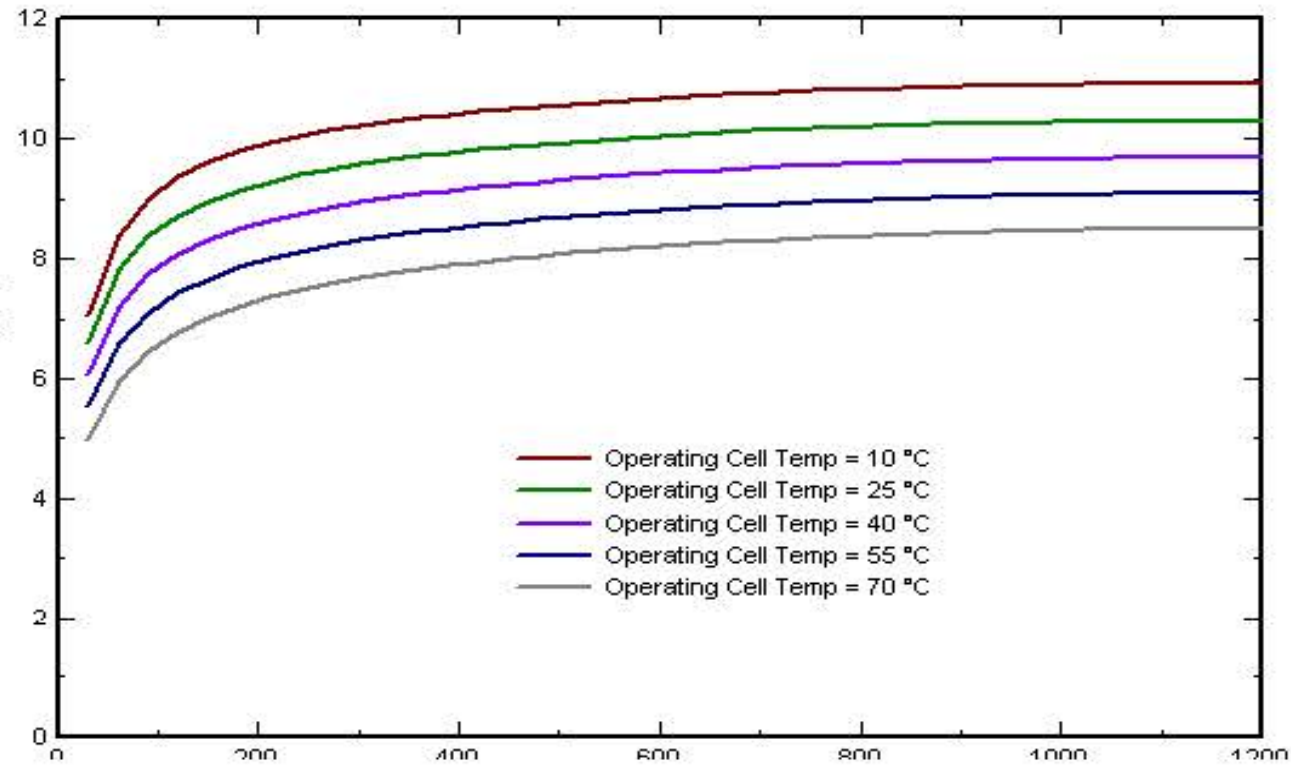

\section{Incident Irradiance $(\mathrm{W} / \mathrm{m} 2)$}

Figure 11. Efficiency with respect to the incident irradiance

Our study has been carried in a town of coordinates $7^{\circ}$ to $8^{\circ}$ degree North latitude Nord, and between $13^{\circ}$ to $14^{\circ}$ degree East longitude. So the panels have been disposed facing south according to cooper equation [6]:

$$
\delta=23,45 \sin \left(2 \pi \frac{284+n}{365}\right)
$$

Where $\mathrm{n}$ is a number that represents the day ( $\mathrm{n}=1$ for January $1^{\text {rst }}, \mathrm{n}=32$ for February $1^{\text {rst}}$ ), $\delta$ the obtained declination to be applied.

We then obtained from PVSyst some useful data of some equatorial towns that might be of great help, this study being concerned as mentioned above (Table 1.a).

Table 1. a: Solar Irradiance and Temperature of some towns (Ndéré means here Ngaoundere town in Cameroon)

\begin{tabular}{|c|c|c|c|c|c|c|c|c|c|c|c|c|c|c|}
\hline & \multicolumn{2}{|c|}{$\begin{array}{c}\text { Ndéré } \\
7^{\circ} \mathrm{N}-13,6^{\circ} \mathrm{E}\end{array}$} & \multicolumn{2}{|c|}{$\begin{array}{c}\text { Garoua } \\
9^{\circ} \mathrm{N}-13,4^{\circ} \mathrm{E}\end{array}$} & \multicolumn{2}{|c|}{$\begin{array}{c}\text { Mora } \\
11^{\circ} \mathrm{N}-14^{\circ} \mathrm{E}\end{array}$} & \multicolumn{2}{|c|}{$\begin{array}{c}\text { Yaoundé } \\
4^{\circ} \mathrm{N}-11,5^{\circ} \mathrm{E}\end{array}$} & \multicolumn{2}{|c|}{$\begin{array}{c}\text { Douala } \\
4^{\circ} \mathrm{N}-9,7^{\circ} \mathrm{E}\end{array}$} & \multicolumn{2}{|c|}{$\begin{array}{c}\text { Tombouctou } \\
17^{\circ} \mathrm{N}-3^{\circ} \mathrm{O}\end{array}$} & \multicolumn{2}{|c|}{$\begin{array}{c}\text { Moscou } \\
56^{\circ} \mathrm{N}-38^{\circ} \mathrm{E}\end{array}$} \\
\hline & $\mathrm{kWh} / \mathrm{m}^{2}$ & ${ }^{\circ} \mathrm{C}$ & $\mathrm{kWh} / \mathrm{m}^{2}$ & ${ }^{\circ} \mathrm{C}$ & $\mathrm{kWh} / \mathrm{m}^{2}$ & ${ }^{\circ} \mathrm{C}$ & $\mathrm{kWh} / \mathrm{m}^{2}$ & ${ }^{\circ} \mathrm{C}$ & $\mathrm{kWh} / \mathrm{m}^{2}$ & ${ }^{\circ} \mathrm{C}$ & $\mathrm{kWh} / \mathrm{m}^{2}$ & ${ }^{\circ} \mathrm{C}$ & $\mathrm{kWh} / \mathrm{m}^{2}$ & ${ }^{\circ} \mathrm{C}$ \\
\hline Janv & 6,44 & 24,7 & 6,01 & 26,3 & 5,57 & 27,8 & 5,50 & 23,2 & 5,56 & 24,6 & 4,91 & 21,8 & 0,50 & $-9,7$ \\
\hline Fev & 6,82 & 26,2 & 6,48 & 28,1 & 6,41 & 30,0 & 5,62 & 23,7 & 5,59 & 24,8 & 5,98 & 24,5 & 0,94 & $-7,7$ \\
\hline Mars & 6,57 & 27,0 & 6,64 & 30,1 & 6,80 & 34,4 & 5,22 & 24,0 & 4,97 & 24,7 & 6,83 & 28,2 & 2,63 & $-2,2$ \\
\hline Avr & 5,80 & 25,5 & 6,30 & 28,9 & 6,58 & 35,7 & 4,94 & 24,2 & 4,57 & 24,7 & 7,26 & 32,1 & 3,07 & 5,8 \\
\hline Mai & 5,42 & 24,4 & 5,88 & 27,1 & 6,37 & 33,4 & 4,62 & 24,0 & 4,41 & 24,5 & 7,45 & 34,2 & 4,69 & 13,1 \\
\hline Jun & 4,99 & 23,2 & 5,48 & 25,5 & 5,95 & 30,0 & 4,33 & 22,9 & 4,02 & 23,6 & 7,27 & 33,0 & 5,44 & 16,6 \\
\hline Jul & 4,66 & 22,2 & 5,07 & 24,4 & 5,36 & 26,0 & 4,06 & 22,2 & 3,46 & 22,8 & 6,93 & 29,9 & 5,51 & 18,2 \\
\hline Aout & 4,67 & 22,1 & 4,92 & 24,2 & 5,07 & 26,4 & 3,99 & 22,3 & 3,08 & 22,8 & 6,62 & 28,7 & 4,26 & 16,4 \\
\hline Sept & 4,80 & 22,5 & 5,23 & 24,8 & 5,61 & 27,9 & 4,26 & 22,5 & 3,45 & 23,0 & 6,65 & 30,5 & 2,34 & 11 \\
\hline Oct & 5,22 & 23,1 & 5,74 & 26,1 & 5,85 & 31,3 & 4,10 & 22,7 & 3,69 & 23,4 & 6,25 & 31,2 & 1,08 & 5,1 \\
\hline Nov & 6,11 & 24,7 & 6,12 & 28,0 & 5,72 & 30,9 & 4,57 & 22,9 & 4,33 & 23,7 & 5,49 & 27,6 & 0,56 & $-1,1$ \\
\hline Dec & 6,25 & 24,9 & 5,90 & 26,9 & 5,33 & 28,3 & 5,60 & 23,0 & 5,13 & 24,1 & 4,72 & 23,3 & 0,36 & $-6,1$ \\
\hline Annual & 5,64 & 24,2 & 5,81 & 26,7 & 5,88 & 30,2 & 4,69 & 23,1 & 4,35 & 23,9 & 6,35 & 28,8 & 2,63 & 5,0 \\
\hline
\end{tabular}

We will now present the testing of specific PV modules and related discussions. We hope this will contribute to provide much deepest insights. We then discuss simulated versus experimental results for a module. The no load output voltage Voc on Figure 5 was 21.6 V and the short circuit current 4.01 A. The no load output voltage Voc was here $21.62 \mathrm{~V}$ and the short circuit current in this case was 4.9 A (Figure 5).
Simulations performed owing to PVSyst indicate that a $20^{\circ}$ declination with $0^{\circ}$ azimuth correspond to the maximum incident irradiance at our experiment geographic point in February. The experiment measurements lead to $25^{\circ}$ declination with $0^{\circ}$ azimuth. Table 1.b gives for the other months the corresponding theoretical and experiments (in blue) positions for maximum incident irradiance. 
Table 1.b: Positions for Maximum incident irradiance during the year

\begin{tabular}{|c|c|c|c|c|c|c|c|c|c|c|c|c|}
\hline Month & Jan & Fév. & Mars & Avr & Mai & Jun & Jul. & Août & Sept & Oct. & Nov. & Déc. \\
\hline Decl & $35^{\circ}$ & $20^{\circ}-$ & $17^{\circ}-$ & $15^{\circ}-$ & $4^{\circ}-$ & $3^{\circ}-$ & $2^{\circ}-$ & $5^{\circ}$ & $7^{\circ}$ & $22^{\circ}$ & $3^{\circ}$ & $4^{\circ}$ \\
Exp & & $25^{\circ}$ & $25^{\circ}$ & $10^{\circ}$ & $5^{\circ}$ & $0^{\circ}$ & $0^{\circ}$ & & \\
\hline $\mathrm{Az}$ & $0^{\circ}$ & $0^{\circ}$ & $0^{\circ}$ & $0^{\circ}$ & $0^{\circ}$ & $0^{\circ}$ & $0^{\circ}$ & $0^{\circ}$ & $0^{\circ}$ & $0^{\circ}$ & $0^{\circ}$ & $0^{\circ}$ \\
\hline
\end{tabular}

Table 2. indicates the theoretical and experiments (in blue) day positions along the month of February

\begin{tabular}{|c|c|c|c|c|c|c|c|c|c|c|c|c|c|}
\hline DTps & $7 \mathrm{~h}$ & $8 \mathrm{~h}$ & $9 \mathrm{~h}$ & $10 \mathrm{~h}$ & $11 \mathrm{~h}$ & $12 \mathrm{~h}$ & $13 \mathrm{~h}$ & $14 \mathrm{~h}$ & $15 \mathrm{~h}$ & $16 \mathrm{~h}$ & $17 \mathrm{~h}$ & $18 \mathrm{~h}$ & $19 \mathrm{~h}$ \\
\hline Decl & $80^{\circ}$ & $70^{\circ}$ & $60^{\circ}$ & $50^{\circ}$ & $40^{\circ}$ & $20^{\circ}$ & $35^{\circ}$ & $40^{\circ}$ & $50^{\circ}$ & $60^{\circ}$ & $70^{\circ}$ & $80^{\circ}$ & - \\
\hline Exp & & & $50^{\circ}$ & $45^{\circ}$ & $35^{\circ}$ & $25^{\circ}$ & $30^{\circ}$ & $36^{\circ}$ & $45^{\circ}$ & $65^{\circ}$ & & & \\
\hline $\mathrm{Az}$ & $-75^{\circ}$ & $-60^{\circ}$ & $-45^{\circ}$ & $-30^{\circ}$ & $-15^{\circ}$ & $0^{\circ}$ & $+20^{\circ}$ & $+35^{\circ}$ & $+45^{\circ}$ & $+50^{\circ}$ & $+60^{\circ}$ & $+75^{\circ}$ & - \\
\hline Exp & & & $-50^{\circ}$ & $-35^{\circ}$ & $-10^{\circ}$ & $0^{\circ}$ & $+25^{\circ}$ & $+30^{\circ}$ & $+50^{\circ}$ & $+50^{\circ}$ & & & \\
\hline
\end{tabular}

Exp: Experiments; Decl: Declination: Az: Azimuth: DTps: Day time

We have then proceed to the characterization of four diffrerent modules through experiments that bring out the Voltage-Current, and Power-Voltage characteristics. (Figure 12, Figure 13, Figure 14, and Figure 15). All those figures present predicted shapes. We can then noticed the
MPP (Imp, Vmp) point for each module as well as the short circuit current.We also have access to the no load voltage Voc, and the slope that leads to the voltage drop (Voc-Vmp).

Module A: Experiments at $10 \mathrm{~h} 20$ at $30^{\circ}, 1^{\mathrm{st}} / 02 / 2013-60 \mathrm{ohms} \mathrm{Load}-1.215 \mathrm{~W}$.

I-V Curve of module A

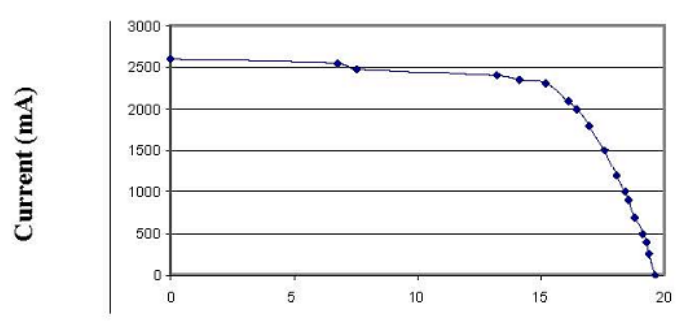

Voltage (V)
Power Curve of module A

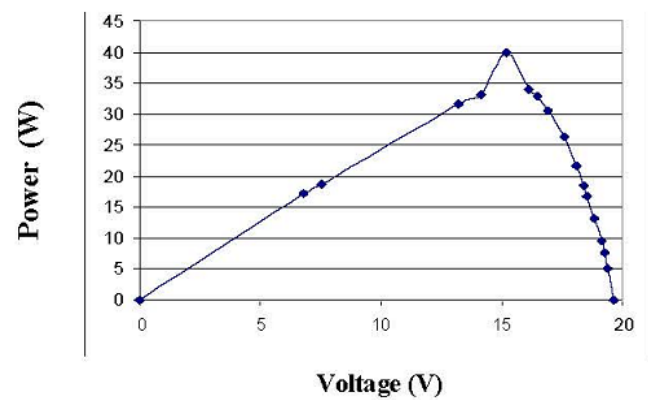

Figure 12. Module A I-V and P-V characteristics

Module B: Experiments at $11 \mathrm{~h} 00$ at $34^{\circ}, 1^{\text {st }} / 02 / 2013-60 \mathrm{ohms}$ Load $-1.215 \mathrm{~W}$.

I-V Curve of module B

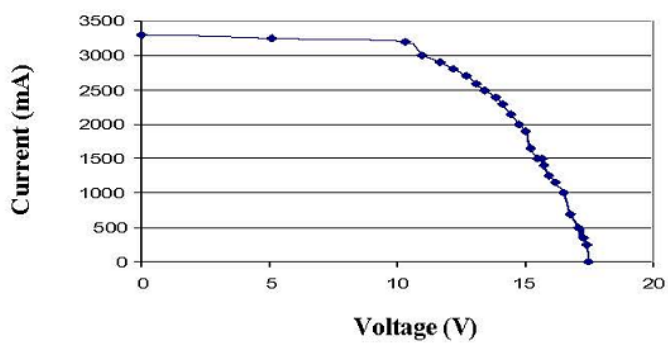

Figure 13. Module B I-V and P-V characteristics
Power Curve of module B

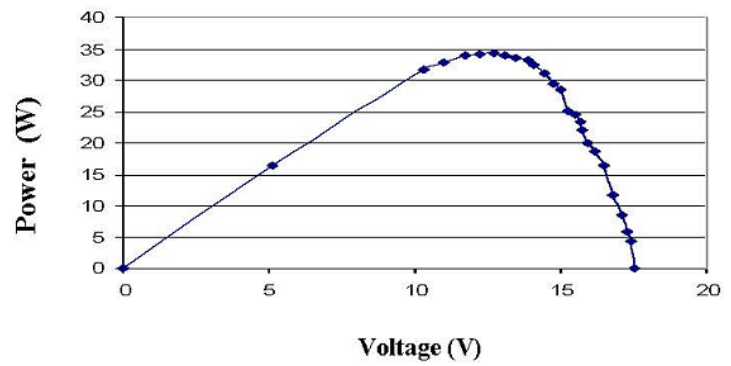

Module C: Experiments at $12 \mathrm{~h} 32$ at $38^{\circ}, 1^{\mathrm{er}} / 02 / 2013-60 \mathrm{ohms} \mathrm{Load}-1.215 \mathrm{~W}$.

I-V Curve of module C.

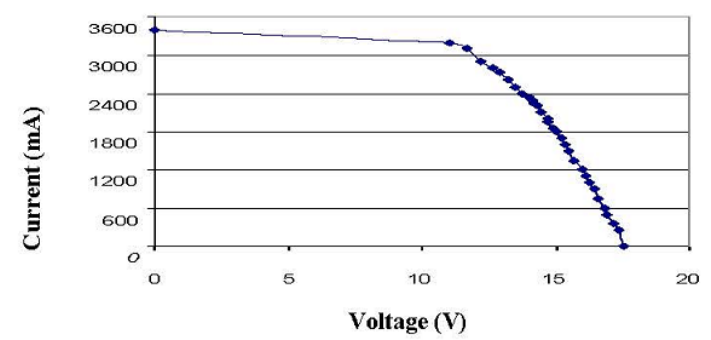

Power Curve of module C

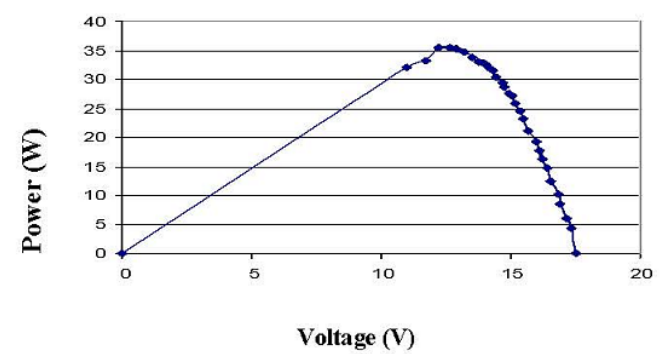

Figure 14. Module C I-V and P-V characteristics 
Module D: Experiments at $12 \mathrm{~h} 12$ at $35^{\circ}-1^{\mathrm{st}} / 02 / 2013-60 \mathrm{ohms} \mathrm{Load}-1.215 \mathrm{~W}$.

I-V Curve of module D.

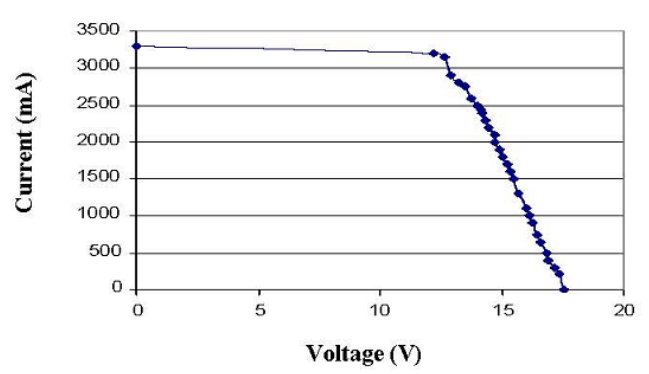

Power Curve of module D

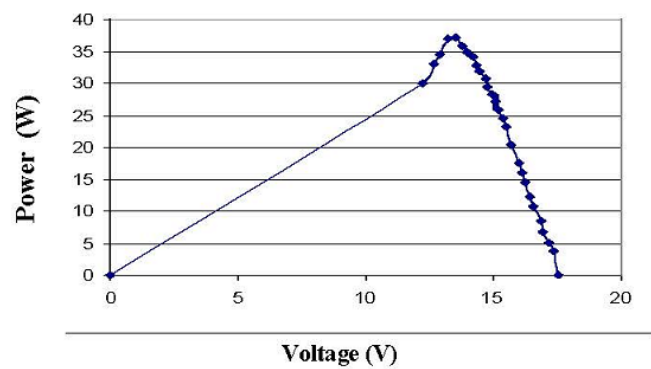

Figure 15. Module D I-V and P-V characteristics

\section{Power (W) Case 12 V}

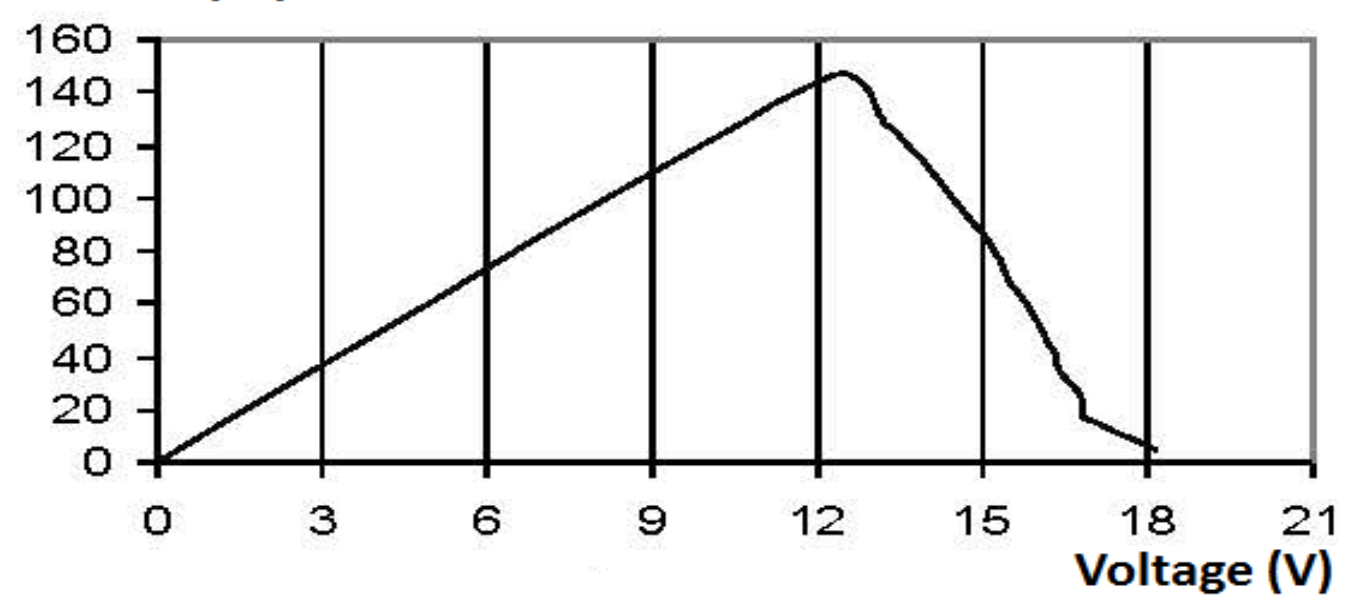

Figure 16. Power Curve of a 12 V PV Panel

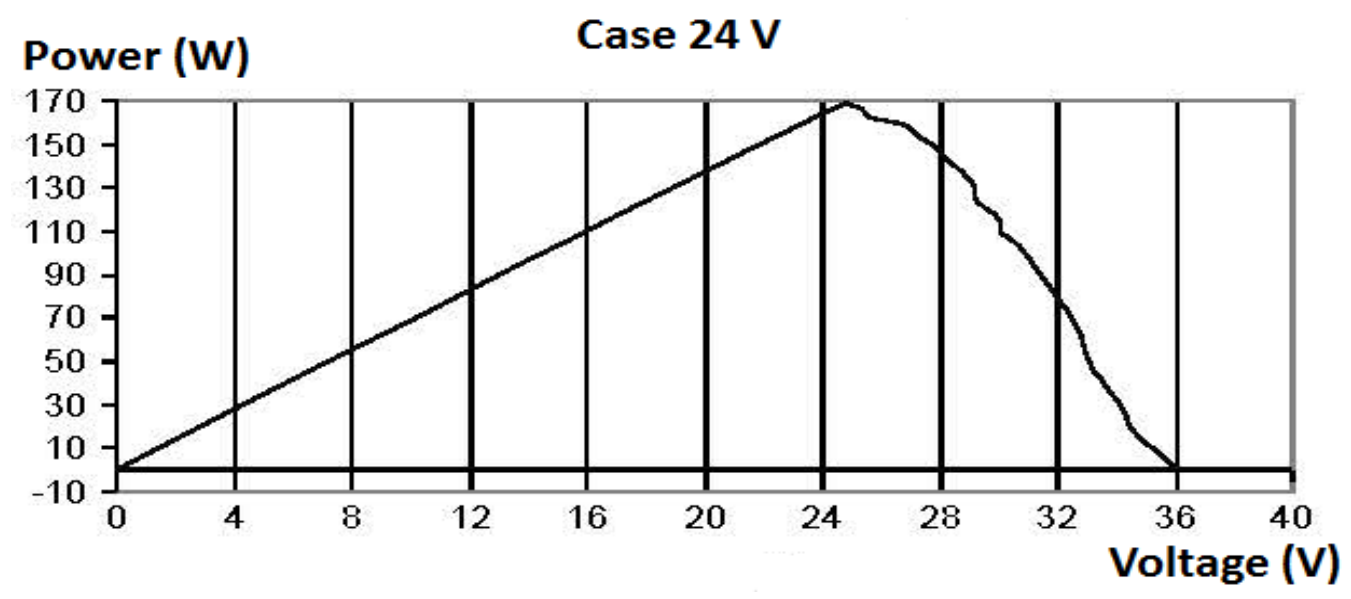

Figure 17. Power Curve of a 24 V PV Panel

Power (W)

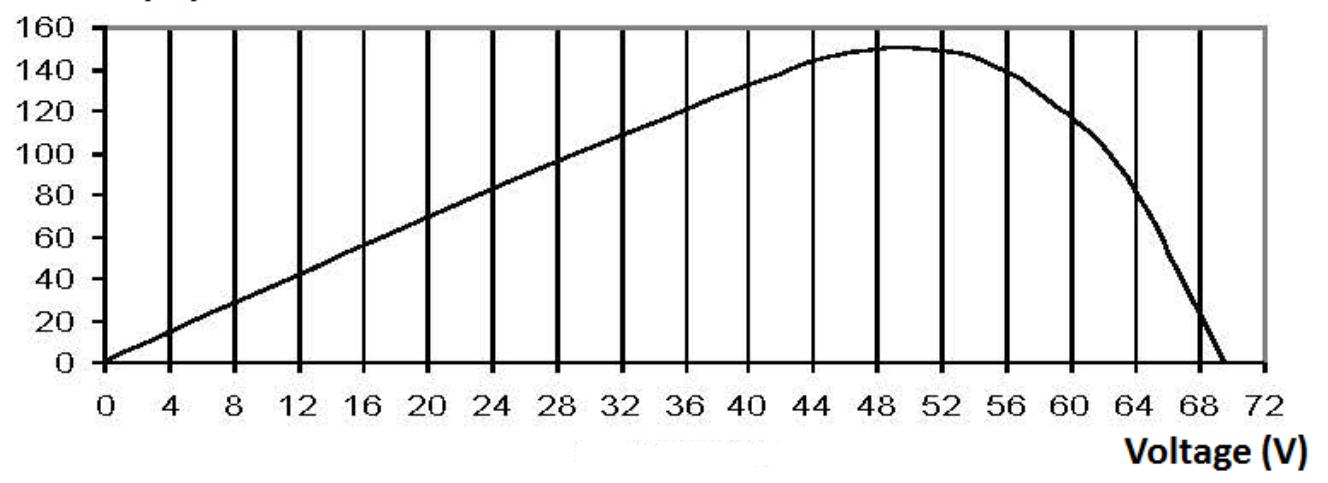

Figure 18. Power Curve of a 48 V PV Panel 
Some other measurements have been carried out on March 25 between one o'clock PM to one thirty the day temperature was $42^{\circ} \mathrm{C}$, the obtained experiments characteristics came to correspond to the expected ones, the maximum power of the $12 \mathrm{~V}$ PV panel was the lowest one $145 \mathrm{~W}$, meanwhile the $24 \mathrm{~V}$ PV panel shown the greatest value of Pmp, 168W. The maximum value of the power delivered by $48 \mathrm{~V}$ PV154W, it so came out that a PV panel system should be characterised before it current used (Figure 16, Figure 17, \& Figure 18).

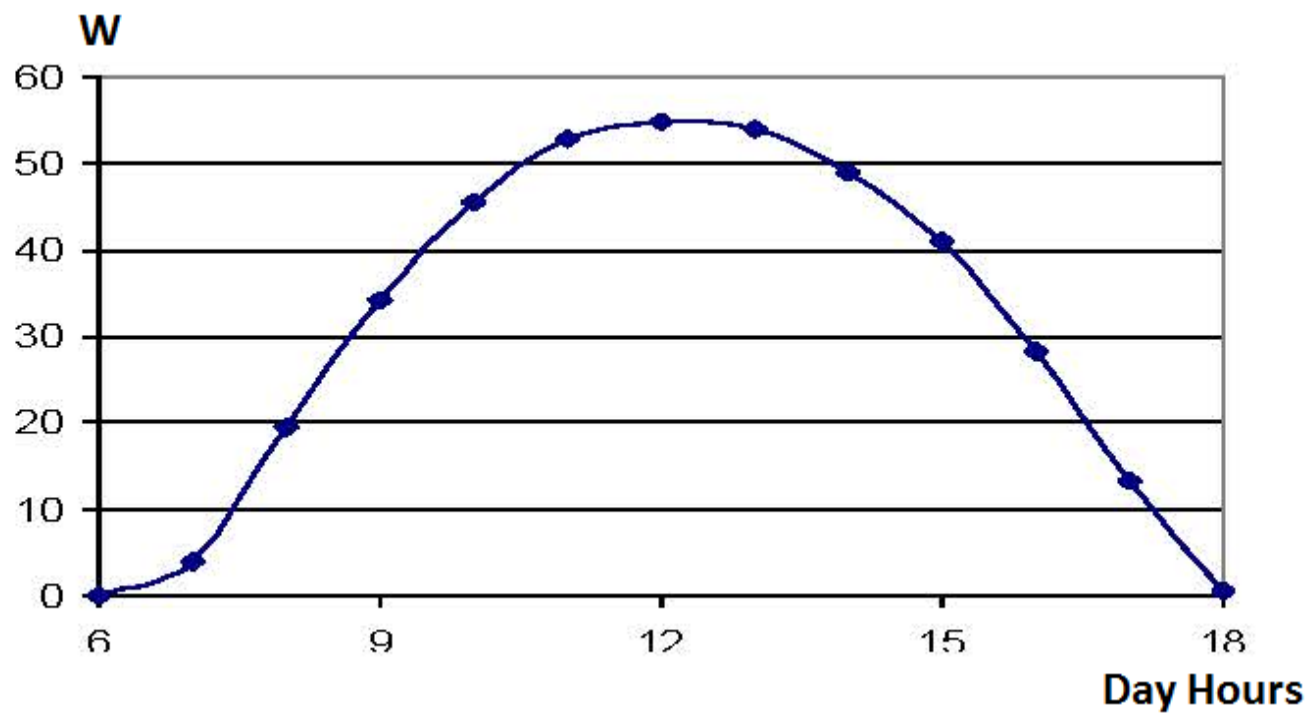

Figure 19. Simulated Power of an horizontal module

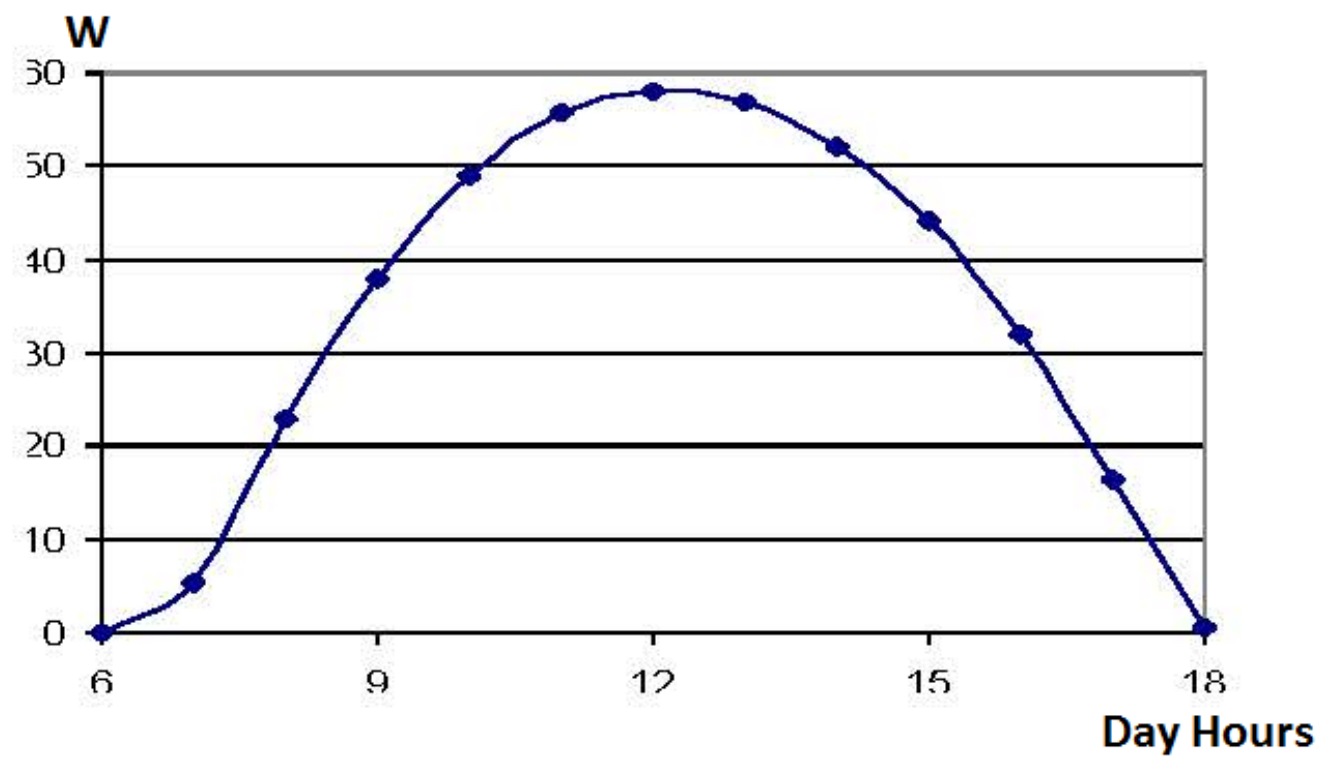

Figure 20. Simulated Power of a $25^{\circ}$ declined module

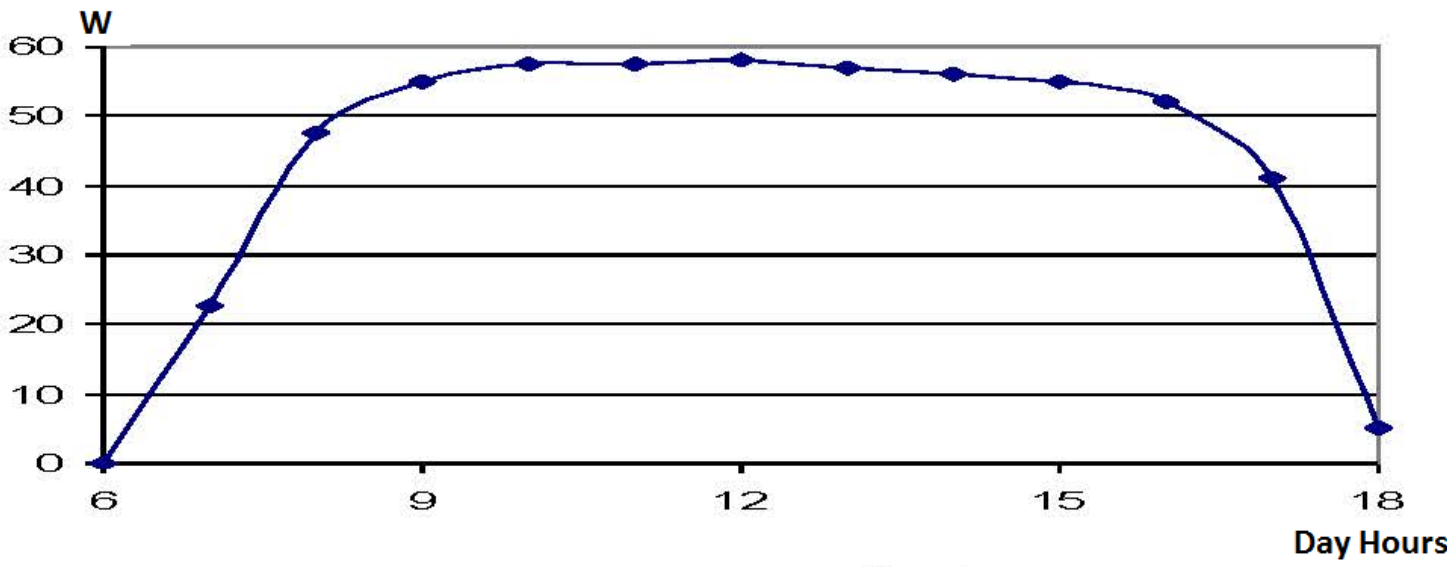

Figure 21. Simulated Power of a module that tracks the sun 
A judicious use of PVSyst based on the parameters of our systems as inputs of the software lead to a quantity of data results among which the solar fluxes, the cell temperatures, the MPP points, and the voltages, results from which we have deduced the Expected behavior
$[9,10,11,12]$ of the power the day along and this according to the geographic position (Figure 19, Figure 20, Figure 21).

We then proceed to experiments, measuring the power with the same conditions. The estimated curves of power correspond to the measured ones [13-20]. The MPP points are almost the same (Figure 22, \& Figure 23).

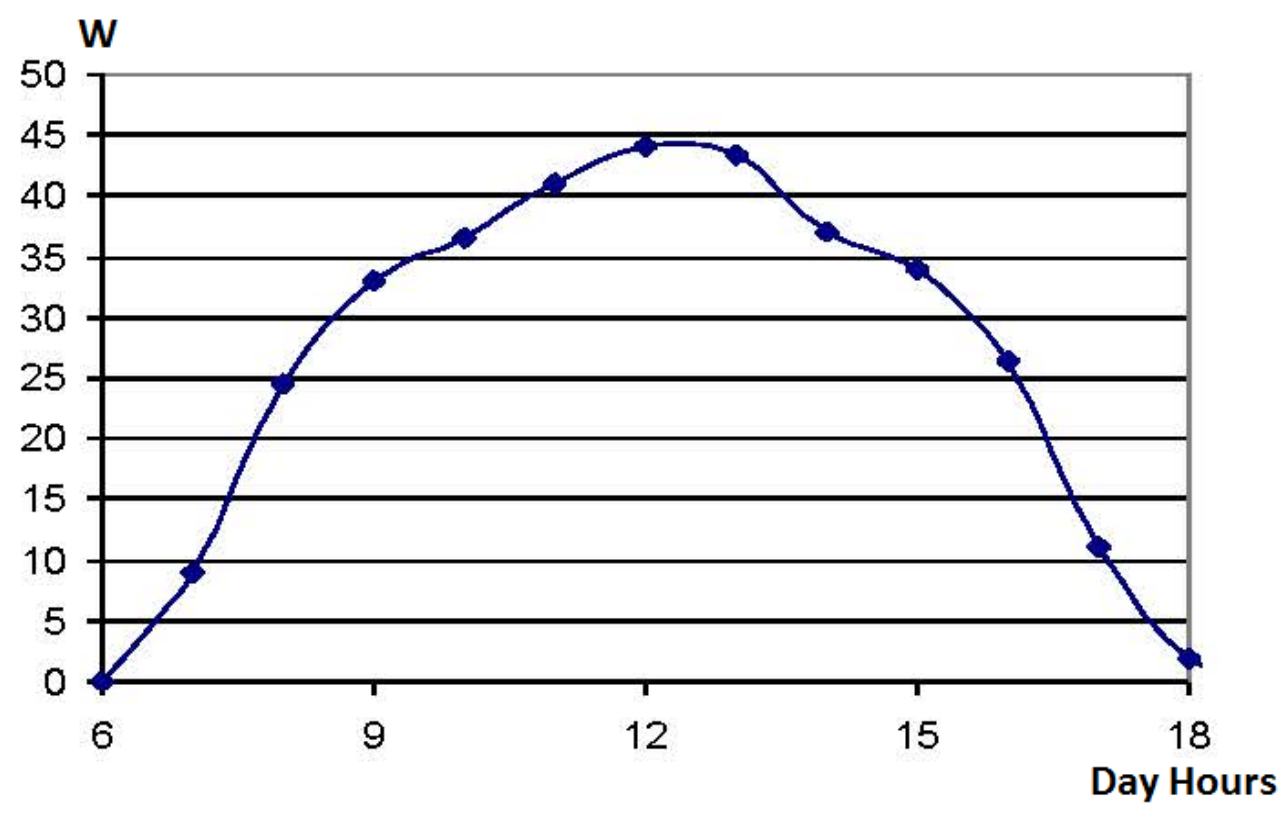

Figure 22. Measured Power of a $10^{\circ}$ declined module

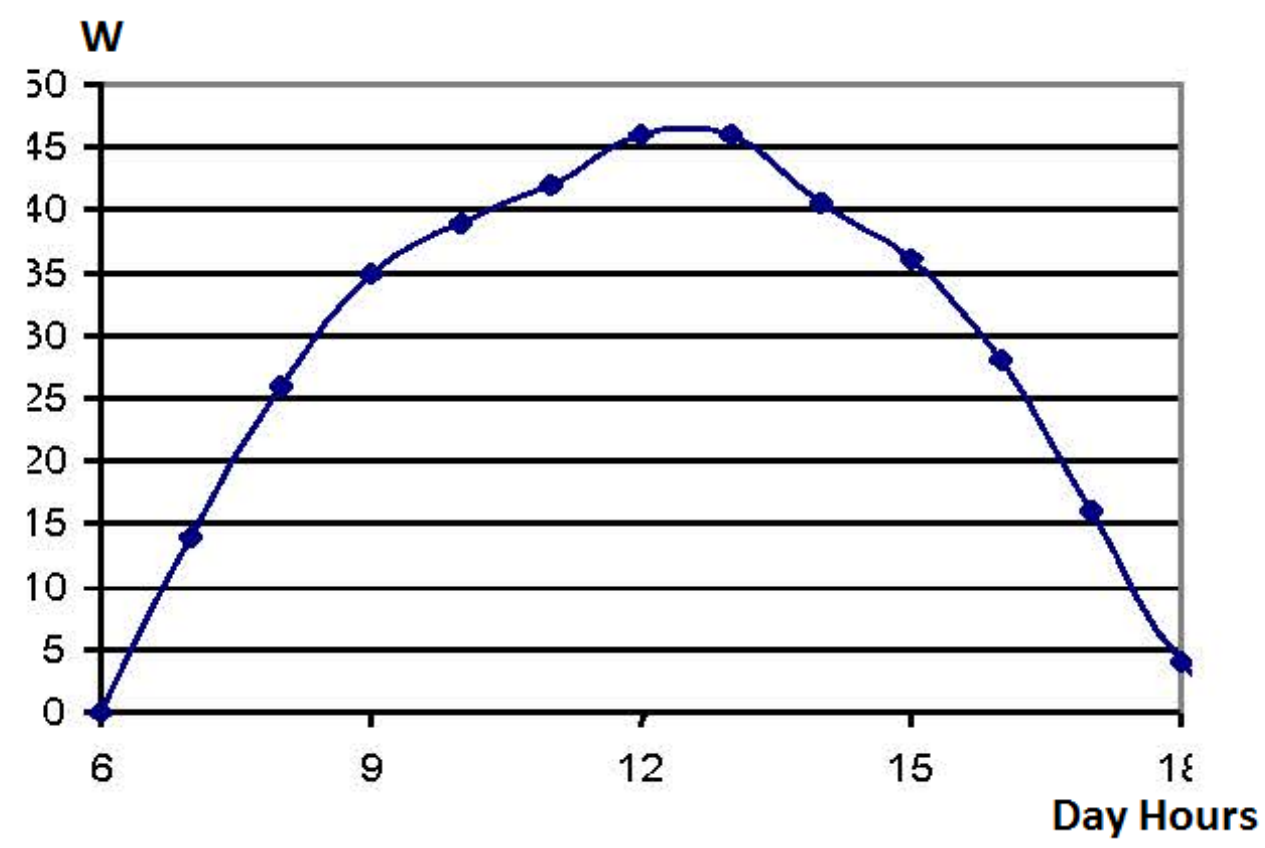

Figure 23. Measured Power of a $25^{\circ}$ declined module

It finally comes out that the best choice of a PV Panel should take into account: The maximum power (Wc), the cell temperature (NOCT), and the certifications IEC 61215 for crystalline modules or IEC 61646 for thin modules. Class protection II (SKL II) should also be respected for safety reasons.

In the study context, economic results shows that the installed PV system will generates $20 \%$ maintenance more that if connected to the grid while the investment is seven times the price for a direct connection to the grid. So we can conclude that PV systems will be more appreciated even in town when the different components will be at accessible prices [6].

\section{Conclusion}

This manuscript discusses several issues related to analysis of PV systems bringing out some insights related to practical deployment in tropic regions. We hope our work constitutes new contributions beyond what is well known from textbooks and scientific literature. We have 
also put on the spot what is readily provided by tools such as PVSyst which has lead to the capability of designing and implementing such PV generators for domestic uses in tropical zone.

We have reached to interesting results related to simulated versus experimental results obtained for a module, and have found be of interest to extend this work further and report the results. For example, have a complete PV system has been installed, and instrumented for data logging. This system had included a battery and an inverter to power real loads over a period of one year. The system design parameters had taken into account the size of the PV array, the battery size, and the power rating of the inverter, as well as the power delivered to the loads. The data logged have so been used to evaluate the designed system and to make assessments on how the system design could be improved so that systems of this type would serve the local needs most economically.

We can here remind that it is important to know how to orientate a PV system depending on the geographic points, the month, and the moment during the day. A PV Panel should also be electrically characterised, its model should so be known and used for predictive needs. The VoltageCurrent and the Power-Voltage curves could then be known leading to use the system with good efficiency. The handling of software such as PVSyst might be also of great helps since it could allow some simulations, and the variations of parameters. It could serve as a guide and may permit comparisons studies. Theoretical and experiments results may then be beneficially confronted. We would like to indicate here that PVsyst Software provides detailed outputs, and useful data bases of sensors, batteries, and inverters, despite the fact that this is not sufficient. Its interface with users seems practice and of easy to use.

\section{Acknowledgements}

Authors would like to acknowledge respectively "École Polytechnique de Montreal”, in Canada, through its Department of Electrical and Computer Sciences and its Laboratory of Electrical Energy, and to "Ecole Nationale Supérieure d'Electricité et de Mécanique de Nancy”, in France, through its Laboratory "Groupe de Recherches en Electrotechnique et Electronique de Nancy”, G.R.E.E.N, both for visitor ships and facilities to Andre YOUMSSI.

\section{Nomenclature}

MPP: Maximum Power Operating Point

AM: Air Mass is an Optical air mass that expresses the mass of the air in atmosphere that the sun radiations go through

Azimuth: orientation with respect to the south counted negatively from the east.

NOCT: Nominal Operating Cell Temperature which is the real operating temperature of the cells of a PV module that operates under $20^{\circ} \mathrm{C}$, with an irradiance of $800 \mathrm{~W} / \mathrm{m}^{2}$, a 1.5 AM spectrum, and a wind velocity of $1 \mathrm{~m} / \mathrm{s}$. Normal values of NOCT are between $45^{\circ}$ and $60^{\circ}$.

PV: Photovoltaic.

LOLP: Loss of Load Probability

IAM: Incidence Angle Modifier.
Icc: Short circuit current of a photovoltaic module

STC: Standard Test Conditions, for an irradiance of $1.000 \mathrm{~W} / \mathrm{m}^{2}$, a $25^{\circ} \mathrm{C}$ junction cell temperature and a 1.5 AM spectrum

Vco: photovoltaic module voltage at no load.

W, kW, MW: Watt, Kilowatt (103), Mégawatt (106).

Wh, kWh: Watt-hour, KiloWatt-hour.

Wc, Wp: Watt peak value, very used for PV cells, Wp is obtained under STC.

\section{References}

[1] Bhattacharjee S \& Bhakta S. "Analysis of system performance indices of PV generator in a cloudburst precinct", Sustainable Energy Technologies and Assessments, vol 4, pp. 62-71, Dec 2013.

[2] K.A kim et al. "Photovoltaic Converter Module Configurations for maximum power point operation”. Proc IEEE Power Energy Conference, pp. 77-82, 2010.

[3] Jih-Sheng Jason Lai et al. "Design of a Photovoltaic simulator with a novel reference signal generator and two Stage LC Output Filter”, IEEE Transactions on Power Electronics, Vol 25, N5, pp. 1331-1338, May 2010.

[4] Teuvo Suntio et al. "Photovoltaic Generators as an input source for Power electronic Converters". IEEE Transactions on Power Electronics, Vol 28, Nº6, pp. 3028-3038, June 2013.

[5] M-F Almi et al. "Protection of hybrid (Wind/Photovoltaic) Generator connected to Mono- phase Electrical Network Supply". Proc the Second International Conference on Informatics Engineering \& Information Science - pp 74-82, 2013.

[6] Jean Zin, l'avenir du solaire, http://perso.orange.fr/marxiens/sciences/solaire.htm, janvier 2008.

[7] Yun Tiam Tan et al. "A model of PV generation suitable for stability analysis”, IEEE Transactions on Energy Conversion, vol 19, Issue 4, pp. 748-755, 2004.

[8] Yang Chen et al. "A cost-effective single-stage inverter with maximum power point tracking", IEEE Transactions on Power Electronics, vol 19, Issue 5, pp. 1289-1294, 2004.

[9] Tina, G.M et al. "Probabilistic energy performance comparison among flat and tracking PV systems", Power Electronics Electrical Drives Automation and Motion (SPEEDAM), 2010 International Symposium on, pp. 169-174, 2010.

[10] Vitorino, M.A. et al. "Using the model of the solar cell Using the model of the solar cell for determining the Maximum power point of photovoltaic systems”, 2007 European Conference on Power Electronics and Applications, pp. 1-10, 2010.

[11] Skoplaki E. \& Palyvos J.A. "On the temperature dependance of photovoltaic module Electrical Performance: A review of efficiency /Power correlations”, Solar Energy, Nº3, pp. 614-624, 2009.

[12] Tahri K \& Benyoucef B. "Modelisation Studies of a Photovoltaic Generator", Journal of Scientific Research, $N^{\circ} 0$, vol 1, pp. 192197, 2010.

[13] Hove T; Manyumbu E; Rukweza G. "Developing an improved global solar radiation map for Zimbabwe through correlating longterm ground- and satellite-based monthly clearness index values", Renewable Energy, vol 63, pp. 687-697, march 2014.

[14] Myers D.R. "Solar Radiation Resource Assessment for Renewable Energy Conversion”, Comprehensive Renewable Energy, Volume 1: Photovoltaic Solar Energy, vol 1, pp. 213-237, 2012

[15] Yeong-Chan Kuo et al. "A high-efficiency single-phase three-wire photovoltaic energy conversion system”. IEEE Transactions on Industrial Electronics, vol 50, Issue 1, pp. 116-122, 2003.

[16] MacAlpine, S.M. et al. "Characterization of Power Optimizer Potential to Increase Energy Capture in Photovoltaic Systems Operating under No uniform Conditions". IEEE Transactions on Power Electronics, vol 28, Issue 6, pp. 2936-2945, 2013.

[17] Bialasiewicz, J.T. "Renewable Energy Systems With Photovoltaic Power Generators: Operation and Modeling” IEEE Transactions on Industrial Electronics, vol 55, Issue 7, pp. 2752-2758, 2008.

[18] Velasco-Quesada, G et al. "Electrical PV Array Reconfiguration Strategy for Energy Extraction Improvement in Grid-Connected PV Systems”, IEEE Transactions on Industrial Electronics, vol 56, Issue 11, pp. 4319-4331, 2009. 
[19] Suntio, T et al. "Issues on Solar-Generator Interfacing With Current-Fed MPP -Tracking Converters”, IEEE Transactions on Power Electronics, vol 25, Issue 9, pp. 2409-2419, 2010.

[20] Poshtkouhi, S et al. "A General Approach for Quantifying the Benefit of Distributed Power Electronics for Fine Grained MPPT in Photovoltaic Applications Using 3-D Modeling”, IEEE
Transactions on Power Electronics, vol 27, Issue 11, pp. 46564666, 2012.

[21] Locment, F et al. "DC Load and Batteries Control DC Load and Batteries Control Limitations for Photovoltaic Systems Experimental Validation", IEEE Transactions on Power Electronics, vol 27, Issue 9, pp. 4030-4038, 2012. 